\title{
Intrahepatic ascariasis leading to liver abscess
}

\begin{abstract}
Ascaris lumbricoides is the most common intestinal worm in the world, with highest prevalence in countries with poor hygiene and sanitation. Our study aimed to report a case of a male patient diagnosed with A. lumbricoides located at the intrahepatic biliary tree who developed sepsis due to intrahepatic abscess. Despite the high incidence of intestinal ascariasis in underdeveloped countries, ectopic forms are still rare. When hepatic abscesses are already formed, the first choice treatment is the drainage and resection of affected liver segments. This case aimed to call attention to the endemic diseases and contextualize the clinical reasoning according to the socioeconomic and epidemiological situation, also emphasizing the importance of effective public health politics working in prevention and health promotion.
\end{abstract}

Keywords: ascaris, liver abscess, laparotomy, intrahepatic biliary, cholangitis, intensive care unit, computerized tomography, postoperative day, GHWA
Volume 3 Issue 4 - 2017

\author{
Menezes Rabelo G,' Benevides de Lima JC, 2 \\ Queiroz da Cunha CM, ${ }^{3}$ Freitas Félix $D,{ }^{3}$ \\ Troiani Neto G, ${ }^{3}$ Correia de Menezes FJ ${ }^{2,4}$ \\ 'Resident of General Surgery, General Hospital Dr.Waldemar \\ Alcântara, Brazil \\ ${ }^{2}$ Department of General surgeon, General Hospital Dr. \\ Waldemar Alcântara, Brazil \\ ${ }^{3}$ University of Fortaleza, Brazil \\ ${ }^{4}$ Department of Medicine, University of Fortaleza, Brazil
}

Correspondence: Francisco Julimar Correia de Menezes, Department of Medicine, University of Fortaleza, Fortaleza, Ceará, Brazil, Email julimarmd@gmail.com

Received: May 19, 2017 | Published: September 05, 2017

\section{Introduction}

Ascaris lumbricoides is the most common intestinal worm in the world, it is estimated that about 1.5billion people worldwide are infected by ascariasis. ${ }^{1}$ Its prevalence is highest in developing countries where low income populations are more susceptible by poor hygiene and sanitation. ${ }^{2-4}$ The larvae are usually ingested through contaminated water or food, and the A. Lumbricoides continuous and intense movements result in migration through the small bowel lumen in the proximal or distal direction. ${ }^{1}$ Thus, there is a risk of reaching holes and invade the biliary or pancreatic tree, and in such cases the most common clinical presentations are biliary colic(56\%), cholangitis $(25 \%)$, acute cholecystitis(13\%) and less commonly hepatic abscesses(1\%). ${ }^{5,6}$ Our study aimed to report a case of a male patient diagnosed with A. lumbricoides located at theintrahepatic biliary tree who developed sepsis due to intrahepatic abscess.

\section{Case description}

A 73year-old male from a neighborhood at the surroundings of Fortaleza (capital of the state of Ceara in the northeast region of Brazil) was received at the Emergency Unit with crampy abdominal pain in epigastric region and right upper quadrant, with irradiation to the back. Lay-jaundiced and had no nausea, vomiting or altered bowel habits. The patient was referred to the General Hospital Dr. Waldemar de Alcântara (GHWA) with diagnosis of cholecystitis and then submitted laboratory tests with the results below (Table 1). Abdominal ultrasound was carried out which showed liver with slightly increased dimensions and hypoechoic collection of 37.6 $\mathrm{cm}^{3}$ in the left lobe with three tubular echogenic images inside, suggestive of ascaris. The gallbladder was distended, thin walled, within thick material suggesting bile, with moderate dilatation of intra and extrahepatic bile ducts and it recorded another suggesting tubular image due to ascaris inside the bile duct which it's measuring was $9.2 \mathrm{~mm}$. Patient presented clinical worsening, being sent to the Intensive Care Unit (ICU) of GHWA with respiratory, renal and haematological dysfunction. After clinical stabilization, computerized tomography $(\mathrm{CT})$ scan of abdomen and pelvis revealed that there was a lobulated and septate collection within gas density focus in the left lobe of liver (segments II and III), which measuring was 8.0x 5.9cm; There also was a collection at subcapsular area, bulging contour in the left lobe of liver (segments IVa and II), which measuring was about $15.1 \times 5.3 \mathrm{~cm}$ it was also detected aerobilia signals and gallbladder fluid level within.

Table I Admissional results of laboratory tests

\begin{tabular}{|c|c|}
\hline Laboratory test & $\begin{array}{l}\text { Result(normal range for } \\
\text { males) }\end{array}$ \\
\hline Hemoglobin $(g / d L)$ & $11.8(12-17)$ \\
\hline Hematocrit (\%) & $33.9(36-50)$ \\
\hline White Blood Cell-WBC (cells $/ \mathrm{mm}^{3}$ ) & $19.524(5-11.000)$ \\
\hline Rods (\% of WBC) & $12(1-5)$ \\
\hline Total Bilirubin (mg/dL) & $5.82(0,3-1,3)$ \\
\hline Indirect Bilirubin/Direct Bilirubin $(\mathrm{mg} / \mathrm{dL})$ & $0,37(0,1-0,4) / 5,45(0,2-0,9)$ \\
\hline PCR* (U/L) & $5,30(0,1-0,5)$ \\
\hline Alkaline Phosphatase(U/L) & $35 I(40-129)$ \\
\hline Gamma Glutamyl Transferase(U/L) & $576(12-73)$ \\
\hline \#AST(U/L) & $162(12-38)$ \\
\hline \#\#ALT (U/L) & $228(7-4 I)$ \\
\hline
\end{tabular}

* Protein chain reaction

\#Aspartate aminotransferase

\#\#Alanine amino transferase

Patient was referred to the operating room, witnessed in surgery moderate amount of ascites and hepatic abscess fluid with several intraparenchymal collections. Cholecystectomy was performed, and during drainage of liver abscesses, slender worm was approximately $20 \mathrm{~cm}$ found in its interior (Figure 1). Followed by intraoperative cholangiogram which showed leak in contrast filling upper biliary tree being held and hepatic hemostasis and drain the remaining collections. Took intensive care following surgery, tracheostomy being made on the 12th postoperative day(PO) per difficult withdrawal from 
mechanical ventilation. Patient experienced gradual improvement and no further complications in the PO. Patient was discharged after fiftythree days of hospitalization.
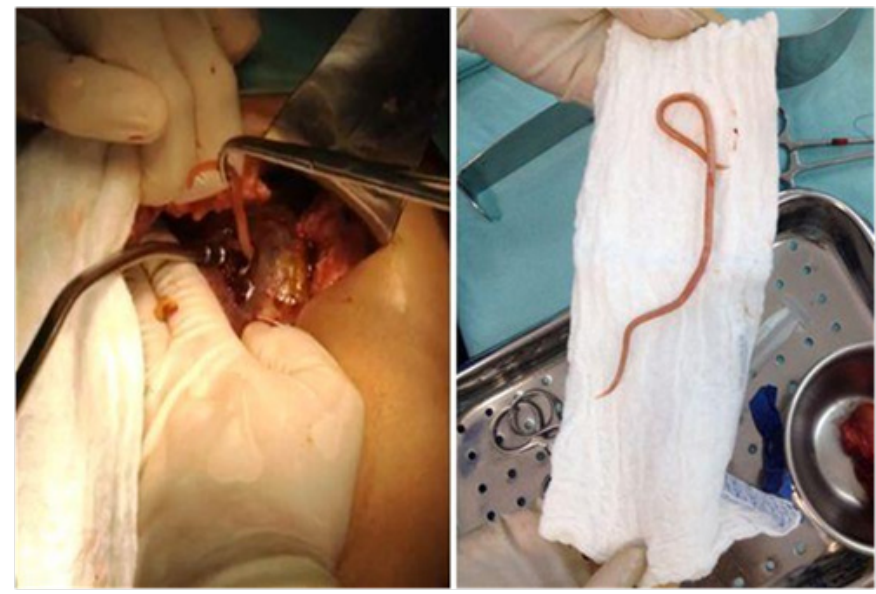

Figure I A. Lumbricoides removed from the liver parenchyma and bile ducts.

\section{Discussion}

Despite the high incidence of intestinal ascariasis in underdeveloped countries ectopic forms are still rare and can affect appendix, pancreatic duct and bile duct hepatic parenchyma. ${ }^{7-9}$ Eggs fragments or parasites present in the bile ducts can enucleating yield calculations and granulomatous hepatitis trigger the production of foreign body granulomas when housed in the liver parenchyma. ${ }^{6,10}$ The abscess occurs when the adult parasite dies within the liver, resulting in a necrotic focus that can become infected later.,

In addition to rare liver abscess caused by Ascaris Lumbricoides presents quite unspecific symptoms and should be suspected in patients with weight loss, malaise, fever, and abdominal pain, usually in the upper right quadrant. Jaundice in liver abscess due to $A$. Lumbricoides is not a common finding, but if it is present is usually related to bile duct obstruction or suppurative cholangitis..$^{1-3,11,10}$ The laboratory tests can reveal changes in liver function, leukocytosis and eosinophilia. ${ }^{1,2}$ Abdominal ultrasound is the imaging method of choice for the diagnosis of bilio-pancreatic complications of ascariasis, the latter has been well stated in the report ${ }^{8}$ In most cases of liver abscess reported by Ascaris, diagnosis occurred in surgery or during autopsy. ${ }^{9}$ The treatment is generally carried out with anti-helmintic drugs and should not be managed in patients with parasites in the bile ducts, for the death of these ones leads to appearance of necrotic focus. ${ }^{8,9,12}$ In such cases endoscopic removal may be performed as other surgical procedures, like choledochotomy or choledochoduodenostomy in case of failure. ${ }^{12,13}$ When hepatic abscesses are already formed, the treatment of choice is the drainage and resection of affected liver segments. In such cases, patients can develop sepsis and even evolve to death (mortality can reach more than $10 \%$ ) if it was not carried out properly during the early course of infestation., ${ }^{4-12}$ Despite of the slow recovery and prolonged hospitalization with intensive care in the PO, in this reported case, death had been avoided fortunately.

\section{Conclusion}

The liver abscess by the migration of ascaris lumbricoides for biliary is a rare complication with few cases reported in the literature, besides exhibiting the high mortality, high costs and prolonged hospitalization therapeutic interventions. The case of this report aimed at drawing attention to the possibility of the disease in endemic and poor sanitation regions, highlighting the importance of contextualizing the clinical reasoning according to the socio-economic reality and be aware of the local epidemiological situation. This case demonstrate the importance of public health policies working in prevention and health promotion which if performed properly could save lives and reduce the expenses involved in more complex treatments relating to complications as well.

\section{Acknowledgements}

None.

\section{Conflict of interest}

Author declares that there is no conflict of interest.

\section{References}

1. Gryscheck RCB, Chieffi PP, Lescano SAZ. Ascaridíase. In: Veronesi, Focaccia, editors. Tratado de infectologia. 4th ed. Ed Atheneu, São Paulo, Brazil; 2009. p. 1829-1834.

2. Mohsen AH, Green ST, Read RC, et al. Liver abscess in adults: ten years experience in a UK centre. QJM. 2002;95(12):797-802.

3. Begum SMKN, Islam QT. Parasitic Liver Abscess Caused By Ascaris Lumbricoides-A Case Report. AKMMC Journal. 2010;1(2):25-26.

4. Medina Andrade LA, Aguilar LB, Duarte EV, et al. Liver Abscess Secondary to Ascaris Lumbricoides: Case Report. Arch Clin Gastroenterol. 2016;2(3):080-082.

5. Freire JEC, Carneiro MA, Carneiro JG, et al. Incidência de Ascaris lumbricoides em mulheres de três bairros de Fortaleza-CE, Brasil. Revista Diálogos Acadêmicos. 2012;1(1):59-65.

6. Castillo EM, González AL. Hepatobiliary ascariasis: A case report. Rev Med Hondur. 2011;79(2):75-78.

7. Pinilla AE, López MC, Ricaurte O, et al. Liver abscess caused by Ascaris lumbricoides: case report. Rev Inst Med Trop Sao Paulo. 2001;43(6):343-346.

8. Malik AH, Saima BD, Wani MY. Management of hepatobiliary and pancreatic ascariasis in children of an endemic area. Pediatr Surg Int. 2006;22(2):164-168.

9. Rahimian J, Wilson T, Oram V, et al. Pyogenic liver abscess: recent trends in etiology and mortality. Clin Infect Dis. 2004;39(11):1654-1659.

10. Zoraida DC, Arredondo C, González I, et al. Absceso hepático ascardiano en la migración errática de Áscaris Lumbricoides en niños. Gen. 2007;61(4):364-366.

11. Pitalua MT, Musoz EM, Villa JG, et al. Ascariasis hepática: reporte de un caso y revisión de la literatura. Salud Uninorte. Barranquilla (Col). 2014;30(2):252-257.

12. Jesus LE, Raposo RP, Guazelli A. Ascaridíase biliar complicada: espectro de problemas e táticas cirúrgicas. Rev Col Bras Cir. 2004;31(3):172-179.

13. Coelho JCU, Freitas AT. Tratamento cirúrgico da icterícia obstrutiva. Medicina, Ribeirão Preto. 1997;30(2):220-233.

14. Villaça EM. As situações das condições de saúde e os sistemas de atenção à saúde. As Redes de atenção a saúde. 2nd ed. Brazil; 2011. 31-35p. 